\title{
Moderating Climate Hazard Risk through Cooperation in Asian Drylands
}

\author{
Troy Sternberg
}

School of Geography, University of Oxford, Oxford OX1 3QY, UK; troy.sternberg@geog.ox.ac.uk

Received: 6 December 2017; Accepted: 5 February 2018; Published: 7 February 2018

\begin{abstract}
Asia drylands face increasing climate hazard risk, changing socio-economic forces, and environmental challenges that affect community viability. As home to $>1$ billion residents, deserts are at the centre of the continent's climate-human predicament. Extreme water scarcity, dependence on food imports and now conflict increase hazard exposure across shared drylands, yet management differs from state to state. This paper argues that a more coherent strategy for mitigating risk would be based on natural environments. Linking hazards with livelihoods and social stability identifies how recent drought events disrupted ecosystems and societies. This results in borders rather than geography defining risk and response. Developing a dryland perspective across the continent can be an effective approach to reduce hazard risk and improve cooperation across Asia's extensive arid lands.
\end{abstract}

Keywords: climate hazard; Asia; drylands; risk; drought; desert

\section{Introduction}

Asia vast desert and semi-desert regions are home to marginal landscapes, expanding populations and significant poverty. Taken as geographical zones, dry areas cover $39 \%$ of the continent and account for $>1$ billion people [1]. These drylands face increasing climate and hazard risk, changing social and economic forces, government (in)action and environmental degradation that affect community viability [2]. The IPCC [3] documents the variability and change in Asian deserts that place them at the centre of the continent's climate-human predicament (Table 1). Extending across nations and regions, dryland environments are shared whilst management differs from state to state. This results in borders rather than geography defining risk, damage and response. A more coherent strategy for mitigating hazards would be based on natural environments and exposure [4]. This paper argues that a continent-wide perspective can be an effective approach to reduce hazard risk in Asia's extensive and diverse drylands.

Asian drylands are important because of their extent and significance in the continent. Covering 18.4 million $\mathrm{km}^{2}$, arid and semi-arid zones are larger and home to more people than Africa [5]. Arcing from the Levant and Arabian Peninsula to the Tibetan Plateau and Gobi Desert, drylands encompass Inner Asian steppes, South Asian plains and Persian Gulf countries [2]. Growing populations, poverty as well as rapid economic growth, water insecurity and human development are common desert themes [1]. These regions share significant environmental challenges and social vulnerability yet are seldom considered part of a connected landscape. This results in climate, risk and hazard engagement being determined by national policy and state capacity rather than on geographical dimensions [6].

Physical, socio-economic and political factors vary between countries, exemplified by government systems, demographics, development trajectories, conflict and mineral wealth [7,8]. Yet most of Asia's dryland areas are united in limited understanding of hazard dynamics and a history of neglect in the development process. This paper moves beyond the standard evaluation paradigm based on country borders to examine climate hazards and risk through a continent-wide dryland perspective. 
Introductory physical factors are presented, climate hazards are identified in Asian deserts and livelihood risks and strategies are evaluated. The role of governance and hazard engagement are considered to evaluate how dryland hazards can best be mitigated across Asia.

Table 1. Recent Asian desert and dryland disasters.

\begin{tabular}{lclll}
\hline Event & Year & Location & Impact & Citation \\
\hline Drought & $2011+$ & Syria & Syrian Civil War & Werrell et al. 2015 [9] \\
Drought & 2011 & Middle East & Arab Spring & Sternberg 2012 [10] \\
Indus flood & 2010 & Pakistan & Displaced 100,000. \$35b damage & Rahim \& Rueff 2017 [11] \\
Extreme heat & 2015 & India & 300,000,000 affected & Em-Dat 2016 [12] \\
Extreme cold & 2010 & Mongolia & GDP loss $-4.4 \%$ & Sternberg 2017 [4] \\
Ice storm & 2008 & China & 77,000,000 affected & Em-Dat 2016 [12] \\
Floods, storms & 2011 & Oman & \$5b damage & Em-Dat 2016 [12] \\
Drought & 2011 & China & Covered 1.3 million km $\mathrm{km}^{2}$ & Em-Dat 2016 [12] \\
\hline
\end{tabular}

\section{Asian Drylands}

Asian drylands are comprised of a subtropical high-pressure belt that extends from Arabia to South Asia and high latitude, cold deserts that stretch from the Aral Sea to Mongolia and China (Figure 1). Arid zones have high evaporation rates due to solar radiation and wind that rapidly removes moisture from the ground surface $[13,14]$; aridity signifies a natural state of endemic low rainfall, limited water availability and high surface evaporation rates [1,15]. Different methods can be used to define drylands, including precipitation levels ( $<250 \mathrm{~mm}$ annual precipitation) and semi-arid regions ( $<500 \mathrm{~mm}$ yearly precipitation) and the Aridity Index (AI) based on moisture availability. The AI is based on climate classification of arid, semi-arid and dry subhumid zones that reflects the ratio of precipitation to potential evapotranspiration (P/PET) (value $<0.03$ hyper-arid, $0.03-0.2$ arid, $0.2-0.5$ semi-arid, $0.5-0.65$ dry sub-humid, $>0.65$ humid) [16]. Climate seasonality, particularly hot and dry conditions, short growing seasons in cold zones and high daily temperature fluctuations restrict plant growth. The scarcity of vegetation and high air movement result in windy conditions that cause frequent dust storms with little or no moisture to hold soil particles [17].

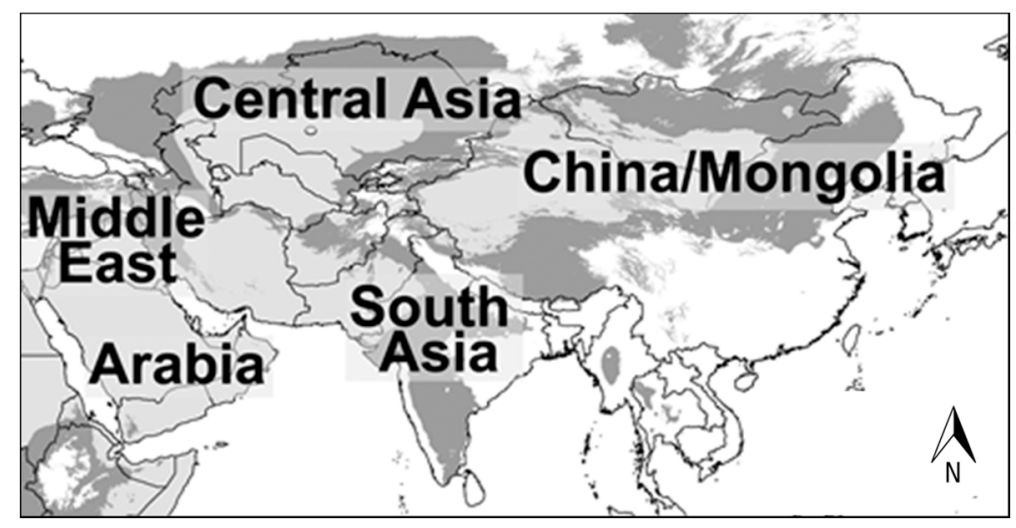

Figure 1. Asian drylands including West (Middle East, Arabia), South, Central and East Asia. Gray = arid $(<250 \mathrm{~mm}$ annual precipitation), black $=$ semi-arid $(<500 \mathrm{~mm}$ annual precipitation [13]. Dryland percentage varies from $\sim 99 \%$ in most of West Asia, to $80 \%$ in Pakistan and Mongolia, 69\% in India and $52 \%$ in China.

The great variety of Asian drylands is in part determined by coastal or inland locations, climate patterns, evapotranspiration rates, elevation, latitude and physical characteristics such as mountain ranges. East Asia's Gobi is a cold, mid-latitude, continental desert [18]; Central Asia is a palaeo-Arctic, biologically rich arid zone, South Asia is home to the monsoon-influenced alluvial plain of the Thar and 
neighbouring semi-arid regions whilst the Arabian desert in West Asia features coastal to mountain topography and a hyper-arid interior $[17,19]$. Each differs in aridity, hazard exposure, resources, infrastructure and tradition yet share similar water, soil and environmental limitations.

Most West and Central Asian states are extremely dry (to 99\%). Even in India and China, commonly thought of as monsoonal or sub-tropical nations, drylands cover a majority of the territory [2]. Whilst there are high temperature clusters in West Asia, the globally coldest states are high latitude Central and East Asia deserts, exemplified by Mongolia, home to the coldest capital city. Significant temperature and climate variability and low moisture limit vegetation and crop production in warm drylands whilst cold environments have low ecological productivity and short frost-free growing seasons. The range and impact of climate hazards are driven by precipitation and extreme weather conditions; risk includes drought, temperature, floods, dust, wind and storm events [20]. For slow-onset disasters that have the highest mortality rates initiation, severity and spatial and temporal extent are hard to identify and quantify [6]. Drought is the most damaging hazard as endemic low moisture, limited ecological productivity and exposed marginal livelihoods increases vulnerability. Events impact meteorological (precipitation), agricultural (water, soil moisture) and hydrological (water supply) parameters [21]. Extremes in heat $\left(>50{ }^{\circ} \mathrm{C}\right)$ and cold $\left(-45^{\circ} \mathrm{C}\right)$ present similar challenges for identification and response. Recent severe and extreme drought in Asia, particularly in 2011, emphasise the physical exposure of continental drylands to climate hazards (Table 2). 
Table 2. Physical data on selected Asian dryland countries (IPCC 2012). Within drylands the data use national capitals to cite temperature, precipitation and drought data.

\begin{tabular}{|c|c|c|c|c|c|c|c|c|c|}
\hline \multirow[b]{2}{*}{ Country } & \multirow[b]{2}{*}{ Capital } & \multirow{2}{*}{$\begin{array}{c}\text { Country } \\
\% \text { Dryland }\end{array}$} & \multirow{2}{*}{$\begin{array}{c}\text { Average } \\
\text { Temperature }\end{array}$} & \multirow{2}{*}{$\begin{array}{c}\text { Temperature } \\
\text { Standard } \\
\text { Deviation }\end{array}$} & \multicolumn{3}{|c|}{ Drought 12 Month Scale } & \multirow{2}{*}{$\begin{array}{c}\text { Capital Precipitation } \\
\text { Avg/Year }\end{array}$} & \multirow[b]{2}{*}{ Flood/Storm Risk } \\
\hline & & & & & $\begin{array}{l}\text { Percent } \\
\text { of Time }\end{array}$ & $\begin{array}{c}\text { Longest } \\
\text { in Months }\end{array}$ & $\begin{array}{c}\text { Last } \\
\text { Severe/Extreme }\end{array}$ & & \\
\hline Afghanistan & Kabul & 94 & 10.1 & 9.0 & 15 & 31 & 2001 & 495.2 & Yes \\
\hline China & Beijing & 52 & 12.2 & 10.9 & 18 & 29 & 2010 & 512.6 & Yes \\
\hline India & New Delhi & 69 & 24.9 & 6.8 & 16 & 23 & 2002 & 708.4 & Yes \\
\hline Iran & Tehran & 90 & 12.8 & 9.7 & 17 & 26 & 2011 & 300.1 & Yes \\
\hline Iraq & Baghdad & 99 & 22.7 & 8.9 & 14 & 35 & 2013 & 140.6 & Yes \\
\hline Jordan & Amman & 99 & 19.0 & 5.9 & 15 & 37 & 2011 & 321.0 & $\sim$ \\
\hline Kazakhstan & Astana & 99 & 2.5 & 13.9 & 15 & 32 & 2011 & 315.0 & $\sim$ \\
\hline Kuwait & KuwaitCity & 99 & 25.6 & 8.7 & 11 & 13 & 2011 & 106.1 & $\sim$ \\
\hline Kyrgyzstan & Bishkek & 80 & 3.9 & 10.5 & 14 & 30 & 2008 & 379.5 & $\sim$ \\
\hline Mongolia & UlanBator & 80 & -2.0 & 14.2 & 15 & 35 & 2012 & 277.8 & Yes \\
\hline Oman & Muscat & 99 & 26.2 & 4.8 & 15 & 21 & 2010 & 72.7 & Yes \\
\hline Pakistan & Islamabad & 80 & 19.8 & 7.2 & 17 & 29 & 2001 & 1075.5 & Yes \\
\hline Qatar & Doha & 99 & 27.4 & 7 & 17 & 11 & 2012 & 74 & $\sim$ \\
\hline Saudi Arabia & Riyadh & 99 & 25.4 & 7.6 & 15 & 35 & 2011 & 103.0 & Yes \\
\hline Syria & Damascus & 98 & 12.4 & 6.8 & 15 & 27 & 2011 & 582.6 & $\sim$ \\
\hline Turkmenistan & Ashkhabad & 99 & 10.4 & 9.7 & 13 & 27 & 2009 & 288.4 & $\sim$ \\
\hline UAE & Abu Dhabi & 99 & 27.2 & 5.7 & 14 & 26 & 2012 & 58.4 & $\sim$ \\
\hline Uzbekistan & Tashkent & 99 & 14.0 & 9.6 & 14 & 55 & 1996 & 383.0 & $\sim$ \\
\hline Yemen & Sanaa & 99 & 15.0 & 3.2 & 15 & 31 & 1991 & 464.0 & $\sim$ \\
\hline
\end{tabular}

Temperature presents average annual and standard deviation (range) from the average. Drought reflects the percentage of time since 1900 in drought, the longest 12 -month drought and most recent severe/extreme events. Precipitation identifies mean annual amount since 1900; cities at flood or storm risk are identified. Climate data are from 1900 to 2013, sourced from the Climate Research Unit, UK global dataset v3.22 [22]. Drought is calculated by the Standard Precipitation Index [10]. See related [5,8]. 
Asian deserts highlight the exposure of drylands to disasters driven by climate and human pressure on environmental resources [3]. Natural limits-water scarcity; low plant productivity and temperature extremes delineate deserts. Changes in climate seasonality, intensity or predictability often result in disproportionate physical impacts [23,24]. For example, shifts in precipitation can have several effects: decreases may initiate drought, increases may cause floods and changes in seasonality affects vegetation growth. Whilst annual precipitation may appear steady, greater intensity leads to high runoff events and leaves less water to provide soil moisture or groundwater recharge. Drought affects plant growth and precipitation shortages reduce subsurface water, water recharge rates and reservoir levels, factors that have significant impact on dryland ecology, physical resources and social development. This reduces dryland productivity, limit ecosystem services and exacerbate human-induced processes (i.e., resource consumption, environmental degradation, desertification). Desertification is often considered a natural hazard yet the concept-a permanent loss of environmental productivity-include physical and human factors [25]. Degraded desert landscapes highlight the reinforcing links between poverty, resource extraction and environmental damage in marginal drylands [26]. The common idea of desertification, from the expansion of the Sahara [27] to the contractions of the Gobi [14] is controversial with responsibility difficult to assign. Vulnerability to physical and socio-political stressors places livelihoods, communities, development and environmental sustainability at the forefront of the climate-human predicament in dryland nations [28].

Environmental risks of degradation and over-exploitation of land and water exacerbate vulnerability. Mao famously declared a 'war on nature' that framed China's engagement with the environment whilst the Soviets initiated the 'conquer the virgin lands' programme in an attempt to farm the Central Asian steppe and desert [29]. Both made land serve the needs of government rather than nature and came to reflect how human action in drylands may reduce productivity and threaten the ability to manage climate disasters. The classic example is the desiccation of Aral Sea in Central Asia that has been identified as the world's worst environmental disaster. As great amounts of water were diverted from the Amu and Syr Darya rivers for agriculture, natural ecosystem processes were disrupted, changing area weather patterns and impoverishing the region.

\section{Livelihoods in Deserts}

Drylands are disproportionately home to poor, climate-dependent residents engaged in agriculture and livestock raising [25]. The UN's Millennium Ecosystem Assessment's identified Asian drylands as the poorest ecological zone with high infant mortality rates and low GDP per capita [30]. Poverty relates to livelihoods exposed to environmental forces: climate risk, water scarcity and marginal lands contribute to low incomes and decreasing community viability. Expanding populations intensify land use and reduce ecological productivity, which increases vulnerability to hazard events [31]. These are significant concerns as research stresses that the social and economic cost of disasters 'are disproportionally borne by poor people in developing countries' ([32], p. 788). Projected greater aridity, widespread droughts and temperature increases are severe threats for very large numbers of people in Asian drylands [24,33].

Poorer, rural, agricultural and animal-raising communities in Asian drylands are vulnerable to climate events where challenges centre on food, water and livelihoods and limited adaptive capacity. Factors that lead to low human development ranking such as income, education, household and institutions and exposure to climate-dependent livelihoods lead to high human vulnerability (Table 3). This is amplified in countries with food and water stress and weak, corrupt or ineffective government institutions, whether democracies or autocracies. The result is hazard risk with few natural processes or societal interventions to reduce risk. The breakdown of governance (Yemen, Syria, parts of the Middle East), migration, displacement to cities, increasing poverty and growing food insecurity stress survival and increase risk. 
Table 3. Socio-economic factors that frame climate hazard risk in Asian drylands.

\begin{tabular}{|c|c|c|c|c|c|c|c|}
\hline & Country & Water & Food & Cultivated & Food & Rural & Human \\
\hline Country & $\begin{array}{l}\text { Population } \\
\text { (Millions) }\end{array}$ & Scarcity & $\begin{array}{c}\% \text { of } \\
\text { Income }\end{array}$ & $\begin{array}{l}\text { Land, ha. } \\
\text { per Capita }\end{array}$ & Imports-Net \% & Population & $\begin{array}{l}\text { Development } \\
\text { Index }\end{array}$ \\
\hline Afghanistan & 32.5 & Extreme & 61 & 0.26 & 70 & 74 & 169 \\
\hline Bahrain & 1.3 & Extreme & 15 & 0 & 18 & 8 & 44 \\
\hline China & 1377.0 & Medium & 36 & 0.08 & 30 & 51 & 101 \\
\hline India & 1311.0 & High & 35 & 0.13 & $\sim$ & 69 & 134 \\
\hline Iran & 79.1 & Extreme & 26 & 0.24 & 38 & 31 & 88 \\
\hline Iraq & 36.4 & High & 41 & 0.14 & $\sim$ & 33 & 132 \\
\hline Israel & 8.1 & Extreme & 17 & 0.04 & 60 & 8 & 17 \\
\hline Jordan & 7.6 & Extreme & 40 & 0.1 & 53 & 18 & 95 \\
\hline Kazakhstan & 17.6 & Extreme & 37 & 1.45 & 32 & 46 & 69 \\
\hline Kuwait & 3.9 & Extreme & 15 & 0 & 96 & 2 & 46 \\
\hline Kyrgyzstan & 5.9 & Extreme & 55 & 0.24 & 3 & 65 & 126 \\
\hline Mongolia & 2.9 & High & 39 & 0.16 & 87 & 32 & 110 \\
\hline Oman & 4.1 & Extreme & 30 & 0.04 & 55 & 27 & 89 \\
\hline Pakistan & 188.9 & Extreme & 46 & 0.16 & 30 & 64 & 145 \\
\hline Qatar & 2.6 & Extreme & 13 & 0.1 & 99 & 17 & 31 \\
\hline Saudi Arabia & 31.5 & Extreme & 23 & 0.12 & 81 & 18 & 56 \\
\hline Syria & 18.5 & High & 42 & 0.42 & $\sim$ & 44 & 119 \\
\hline Turkey & 78.6 & High & 25 & 0.26 & $\sim$ & 26 & 69 \\
\hline Turkmenistan & 5.3 & Extreme & 32 & 0.35 & 96 & 52 & 102 \\
\hline UAE & 9.1 & Extreme & 9 & 0.01 & 95 & 16 & 30 \\
\hline Uzbekistan & 29.9 & Extreme & 35 & 0.21 & $\sim$ & 64 & 115 \\
\hline Yemen & 26.8 & Extreme & 45 & 0.05 & 86 & 68 & 154 \\
\hline
\end{tabular}

Data from $[8,34-36]$ and related sources.

\subsection{Social Impacts}

Desert countries have severe water scarcity and low availability of arable land, and significant food imports are needed in several countries (see Table 3). Within this context hazards become stress multipliers as climate affects land productivity. Higher income countries have the means to address issues through infrastructure, desalination, advanced technology, intensive agriculture and have money to import food. Indeed, rich countries may disregard nature, as the UAE consumes the most water per capita in the world. For poorer nations, the uncertainty of water for agriculture and lack of disaster mitigation exacerbates risk for rural populations. These nations also spend a high percentage of income on food and depend heavily on bread for calorie intake; several states spend $>35 \%$ of household income on food (Table 3), in contrast with $9 \%$ in the UK.

Whilst the immediate burden of hazards is greater in rural regions, urban centres face indirect climate exposure to water and food supply. Much water is delivered through mega-projects, such as the South to North Water Transfer Scheme in China, major dam projects such as the GAP in Turkey, canals in India and desalination plants across the Gulf States [37]. These reflect the continual effort to supply adequate water for large urban centres, usually at great financial cost, and are coupled with high groundwater (over)-extraction rates. Floods and storms occurring in drylands (e.g., in Pakistan, Oman) damage communities and infrastructure and, because of intensity, the water is not stored for later use. In rural areas, disaster affects cropland and small communities, whereas in cities, disaster has high economic and human cost because of density and development levels.

As nations pursue different development paths, their ability to prepare and mitigate climate events vary greatly. Asian pastoralism presents several approaches to a shared traditional lifestyle that can be a source of resilience. In Gulf States, herders are maintained as cultural artefacts, supported by government programmes providing fodder and water delivery, factors that greatly reduce risk. Herding continues in western India, parts of Pakistan, Iran and Iraq and to some degree amongst Bedouin in the Middle East, regions where hazard vulnerability is framed by poverty, exclusion, lack of government support and marginalisation within the larger society. In Mongolia, transhumant herders cope with hazards through traditional mobility and land use practices. When winter disaster 
strikes, it in part reflects limited planning, lack of preparation and the state's inability to mitigate and adequately respond to disaster. The country's recent pattern reflects poor nations' reliance on external assistance for local conditions.

\subsection{Governance and the State}

Government goals, programmes and capacity are key to hazard management and reduced human vulnerability. Effective policy can be the most important factor in providing direction and support to mitigate hazards and be shared amongst nations. In contrast, failure to engage can lead to climate disasters. Examples of actions increasing exposure include expanding farmland in dry areas, crop selection, water diversion, reliance on engineered solutions, disregarding environmental conditions, policies to settle 'backwards' pastoralists, siting of urban centres and poor disaster planning and response are common factors in most countries. Short-term focus on economic growth, favoured political groups and industries, land degradation and lack of investment or interest exacerbates matters. Asian dryland states have joined international disaster frameworks, yet recent crises (see Table 1) suggest that improved mitigation is lacking.

Countries and regions differ in aridity, hazard exposure, resources, infrastructure and tradition across Asia yet share similar water, soil, environmental and social limitations. Developed desert nations (the Gulf States, Israel) with advanced technological processes can inform and improve dryland lives beyond national borders. Middle-income countries (China, Iran) may embrace progressive approaches and have mitigation capacity whilst also maintaining local methods. Developing states (Mongolia, Jordan) and poor nations (Yemen, Uzbekistan) can benefit from research, experience and practice aligned with customary actions. A balance is needed-China's powerful government has shown the ability to respond to disasters yet environmental degradation, intensified land use and pollution increase vulnerability; Mongolia exhibits natural resilience through mobility but has little response capability. High population density, monsoonal floods and human-induced degradation lead to vulnerability in South Asia whilst population, conflict, water scarcity and reliance on food imports characterise West Asia [17].

A country's self-perception and political realities affect hazard engagement. China stresses the temperate and sub-tropical central and southern Han heartland within the Great Wall though the vast arid north and west (52\% of land) face challenges similar to other arid countries rather than with southeastern China. In the desert region (Taklamakan, Gobi), climate exacerbates exposure due to a lack of water sources, poor soils, drought and extreme cold. Contrasting hazard risks are also found in differences between India's arid northwest and monsoonal south. The significant pan-desert similarities and challenges should encourage cross-border discussion and interaction to develop effective disaster mitigation strategies and measures.

Forms of governance have a big impact on how policy is set, funds are spent, citizens aare engaged and programmes are implemented. Desert nations are led by kings and a sultan, one party states, ex-communist dictators, theocracies to democracies and failing states. Persian Gulf countries have used infrastructure and trade to reduce citizen's climate dependency. Other authoritarian systems (Central Asia) may be slow to prepare and react and blame nature when climate events strike. Democracies respond to public interests and pressure though disaster response may depend on financial ability and effective implementation. Israel mitigates drought through technology whilst after a winter disaster Mongolia waits for aid, Pakistan seeks international relief to deal with flooded drylands and India copes with drought and falling water levels. Political capacity and attention is key to reducing human risk whether driven by elections, economics or fear of unrest and instability.

\section{Hazards in Context}

The most striking example of hazard-human interaction is the role of drought in the Arab Uprisings and now the collapse of governance in parts of the Middle East [9,10,38]. Extreme drought from 2006 to 2011 in northeastern Syria in combination with the hottest temperature in 
100 years resulted in 75\% crop failure, $85 \%$ animal mortality and displaced 1.5 million people [38]. The drought contributed to a 'perfect storm' of physical exposure, socio-economic vulnerability and poor governance that led to high out migration to cities [10]. Loss of livelihoods, inadequate and heavy-handed government policies, selective aid or lack of response and relief resulted in 2-3 million people experiencing extreme poverty and displacement, causal factors of protest, conflict and civil war $[9,39]$. Drought exacerbated existing social challenges including marginalisation of minority farmers and herders, unequal access to water, resources diverted to cities and policy favouring elite groups.

A second climate example reflects the international scale at which hazards can operate. In 2010-2011, an extreme drought and fires on the Asian steppe and in China's wheat growing region had a major impact on wheat imports in the water-scarce Middle East [10]. This reduced harvests and threatened supply, leading China to purchase large volumes of wheat on international commodity markets. The process disrupted the wheat fungibility, led to wholesale prices doubling and a reallocation of global supply. The resulting distribution shortages were particularly harsh for importing nations, the top nine all located in the Middle East. Most affected was Egypt, the world's largest wheat importer, where wheat prices tripled and shortages led to bread riots and deaths and merged with political protests. Natural limitations to food supply in the water-scarce regions highlights how drylands are both high net food importers (Kuwait and Turkmenistan-96\%; Mongolia, Saudi Arabia, Yemen $\longrightarrow 80 \%$ ) and spend much of household income on food (Afghanistan-61\%, Kyrgyzstan-55\%, Pakistan, Syria, Yemen $\rightarrow 42 \%$ ) (Table 2). Processes reflect the potential for hazards both exacerbate food insecurity and to have global implications far beyond local or regional scales where hazards are usually examined.

As these examples show, much depends on governance-the drought case studies provide opposing examples. Though in Syria a new Drought Management Plan was put in place with UN coordination in 2006 [40], President Assad did not adequately address the disaster or assist affected residents. Social processes spiraled out of control as cohesion collapsed and conflict ensued. In contrast, the Chinese Communist Party made significant efforts to alleviate drought impacts to maintain livelihoods and minimise unrest. Both were autocratic governments; one worked to preserve social stability, the other pursed development that marginalized rural populations at great national cost.

A striking shortcoming of international relations, development and relief aid is that climate policy, hazard preparedness and disaster assistance are defined nationally rather than based on environments, biomes or common landscapes. This means neighbouring states are limited to local capacity and structures and that best practices often stop at borders. As Asian drylands cover the development spectrum, there is much information, practice and expertise that can be shared. Yet a lack of interaction, knowledge and experience leaves disasters widespread but mitigation strategies country-specific. The outcome is that transboundary cooperation and skills transfer seldom occurs though the international nature of hazards encourages coordination amongst states.

Oddly, desert nations seldom talk about hazard environments, particularly across regions. Where are international organisations or fora that engage with desert issues? Hazard dynamics are constrained by borders rather than presented as climatological and geographical zones. This means that engagement, mitigation and response occur on a state by state basis rather than on events, spatial scale (particularly drought, temperature extreme), watershed (drought, flood), risk or linked problems (dust source, storm, area of impact). This isolationist approach results from how nations and borders are conceived, limited capacity, costs/funding, donor organisations' country-specific focus and inertia. Though international efforts, such as the Hyogo Framework and UNISDR (United Nations International Strategy for Disaster Reduction) [41], encourage disaster risk reduction, results have not led to effective strategies. Natural partners abound in Asia's desert regions that share similar threats, episodes and social histories. Across the dryland development spectrum expertise on reducing risk, disaster cooperation and skills transfer between arid zones can be geographically linked. For example, 
factors that reduce hazard vulnerability-finding water, improved irrigation, drought tolerant crops, sustainable land use, rural preparedness—can be transferred across desert areas.

\section{Discussion}

The intricate relationship between hazards, environments and society creates socio-political implications for citizens and states. Hazards serve as unforeseen trigger events-think of drought affecting water resources, crop production, food supply and instigating migration, civil strife and disrupting governments as in the Syrian example. As endemic challenges in drylands, external climate events impact community and landscape resilience and well-being [4]. The stress on physical landscapes and social systems (Tables 2 and 3) reflect their marginal environments and livelihoods. These have a significant impact on populations and governments at domestic, transboundary, regional and continental scales as climate exposure threatens livelihoods, communities, resources and economics [42,43]. Disasters then become part of 'hazard globalization' as events that occur in one region can have a dramatic follow-on impact across borders and continents. A topical example is Sternberg's [10] article on 'Chinese drought, bread and the Arab Spring' that stresses the continent-wide scope of hazard impacts as they threaten food supply and social stability.

In Asian deserts there is limited climate hazard investigation and attention, reflecting the low priority given to hazards relative to other pressing problems. Except for China, climate hazard research and engagement is weak in South and Central Asia whilst there is a dearth of studies in the Middle East and Arabia. The result is that international agencies and donor organisations often set the tone for hazard engagement through control of funding and assistance. In this approach, affected dryland countries (as requesters) have limited ability to put forth a local perspective or lack the scientific grounding to argue or advance policy and practice beyond current coping mechanisms. Donor agency focus is on immediate conditions rather than on developing in-depth knowledge or new approaches, exemplified by recent Pakistani floods and Mongolian extreme cold events where relief repeats prior efforts. The knowledge gap creates a negative feedback loop where humanitarian efforts base decisions on existing and past practice rather that on contemporary investigation and quantification of climate hazards.

The constraints imposed (funding, borders, skills) by existing structures (states, international and donor agencies) are poorly suited to today's Asia. Improved cooperation across arid nations and regions offers a great opportunity to strengthen hazard mitigation. This can commence with planning and preparedness and address response and system resilience. Many concepts are holdovers from previous eras when climate was inadequately understood, development and infrastructure was moderate, international organisations were being formed after World War II (UN, aid agencies) and the nation state embodied permanence. Yet since 1970, Asia's population has doubled [44]; with this political and economic power have transitioned in the region. Whilst the past Soviet vs. American and first vs. third world global dynamics have faded politically, the rigid configuration of hazards as national rather than geographical events endures. Greater knowledge of climate and hazard parameters, growing recognition and appreciation of their disruptive role and awareness of the significant direct and collateral damage hazards impose give the motivation for reworking hazard engagement to reflect Asian realities. Indeed, contemporary hazard crises identify climate as a threat to progress and human well-being.

The vulnerability of deserts to climate hazards can be parsed in many ways. First is to recognize that climate hazard exposure in drylands differs from temperate and tropical zones [6]. The reduced adaptive capacity due to marginal environments and physical resource limitations is critical. Societies have been able to build cities and make the desert bloom, but this creates dependence on diverse and often distant water sources and increases exposure to climate. The heightened risk factor means drylands present different vulnerability scenarios than other eco-zones. Further, the theme of marginality runs through deserts in nature and livelihoods as dominant dryland dwellers-farmers and livestock-raisers-remain dependent on climate, ecology and landscapes. 
The immediacy presented by conflict, war, migration and refugees in West Asia are such direct threats that focus on climatic causation is lost. As turmoil engulfs the region less attention is given to the major role of climate and environment in society. Who is growing the food, maintaining infrastructure, developing new water sources in the extensive battle zones? Where are buffer systems in place to cope with temperature stress or lack of rain, or reduced harvests? How do functioning states like Jordan or Lebanon provide water for 2 million refugees in a sustainable way? War and insurgency present several challenges that in such humanitarian disasters climate factors are seldom noticed. What sounds like a water supply problem is also a climate matter as precipitation ultimately controls water resources, groundwater recharge and the viability of rainfed agriculture. As climate stresses food production, community vulnerability increases commensurately. In the populated, marginal environments, moderate changes in precipitation can have exponential impact. In Syria, drought acted as a trigger event; what may be the climatic cause of future insecurity?

\section{New Directions}

Drawing on existing and future scenarios, there are several directions to enhance cooperation in drylands. The main challenge is re-orienting state to state and international focus to address hazards. Broadly, these could evolve from current collaborations in Asian deserts, shared global dryland praxis and from growing Chinese interaction across the continent. For instance, Pakistan and India have cooperated on the Indus Waters Treaty since 1960, Saudi Arabia and Jordan signed an agreement in 2015 to protect the shared Disi Aquifer and Israel-Palestine-Jordan have proposed the Red Sea to Dead Sea Water Conveyance. Each is an example of trans-national cooperation to resolve water imperatives that can encourage similar action [45]. More of these initiatives can stress climate hazards to overcome state bureaucracy and inflexibility with efforts can be encouraged by regional institutions (Arab League, Gulf Cooperation Council, Central Asia's Program on Mutual Cooperation).

The roles of international fora (UN, World Bank, aid programs) can be reconceived to move beyond a country-specific focus to shape transnational approaches. Focus on meeting broad agendas can foster joint country efforts under the auspices of the UN's Convention to Combat Desertification, Paris Climate Agreement and the UN's Framework Convention on Climate Change. CGIAR and ICARDA already work in drylands; their approach could naturally embrace climate hazard risks. Asia receives $71 \%$ of the GCC's $\$ 1.7$ billion aid budget—resilience could become part of this. Further, transnational exchanges (such as the British Council's water research programme), technological advancements developed locally (such as in irrigation and desalination) and academic research on arid zone hazards [6] can push knowledge beyond narrow boundaries.

New Chinese interest through the Asian Infrastructure Investment Bank (AIIB) and the \$1 trillion One Belt, One Road initiative may offer an unexpected route to better cooperation on climate hazards [46]. Investments include water and agriculture; with a dominant lender, economies of scale and cooperative host countries China can overcome previous state-state reluctance with superpower focus on project delivery. The AIIB can provide institutional funding to bridge technological gaps between countries. China's exposure, attention and knowledge about climate hazards [47] can be part of the New Silk Road's benefit. Action in other arid regions, such as the Southern African Development Community's vulnerability analysis [48] and the Committee for Drought Control in the Sahel's focus on sustainability could feature in an Asian dryland network. These new directions first build on existing cooperation, then foster broad-based, multi-state or institution initiatives to encourage transnational hazard interaction.

\section{Conclusions}

This paper started with information about climate extremes, vast Asian deserts, population exposure and rising threats to the environmental and social status quo. Research reflects the variegated dryland conditions, divergent ways to mitigate climate (development, tradition, infrastructure), implied vulnerability of hundreds of millions of poor farmers and animal raisers 
and the disconnected framework and lack of hazard cooperation and mitigation within and across nations [4]. This unproductive, even dysfunctional socio-climatic landscape ignores both the abrupt power of natural events and the capacity of humans to address and resolve threats to stability and survival. The global risk is in not understanding how changing climates affect societies in marginal environments; the task is to reconfigure climate engagement away from an abstract science to today's imperative knowledge.

For states the challenge is to adapt, build resilience and address vulnerability, realising that events can affect political viability, as well as national security and regional stability. Syria presents the cost of neglect and emphasises that hazards are delineated by environment rather borders. The personal, community and societal threat is great enough that the imperative is to 'integrate climate change adaptation with disaster risk reduction' ([49], p. 10) at national, regional and continental levels. In today's interconnected planet climate hazards, like people, goods or money, provide new representations of our globalised world. In this arena encouraging trans-national perspectives and improved cooperation can reduce hazard risk to climate hazards across Asian drylands.

Acknowledgments: This is revised and shortened presentation of the theme that appeared in Climate Hazard Crises in Asian Societies and Environments. 2017, Routledge: Abingdon, UK. We thank the publisher for permission to present as a journal article. The Oxford Desert Conference series and John Fell Fund support were integral to the conception and writing of the paper.

Conflicts of Interest: The author declares no conflict of interest.

\section{References}

1. FAO. Drylands, people and land use. In Water and Cereals in Drylands; Koohafkan, P., Stewart, B.A., Eds.; Earthscan: London, UK, 2008; Available online: fao.org/docrep/012/i0372e/i0372e01.pdf (accessed on 14 September 2015).

2. Prăvălie, R. Drylands extent and environmental issues. A global approach. Earth Sci. Rev. 2016, 161, $259-278$. [CrossRef]

3. IPCC. Climate Change 2014: Impacts, Adaptation, and Vulnerability. 2014. Available online: http:/ / www. ipcc.ch/report/ar5/wg2/ (accessed on 15 May 2015).

4. Sternberg, T. Climate Hazard Crises in Asian Drylands. In Climate Hazard Crises in Asian Societies and Environments; Sternberg, T., Ed.; Routledge: Abingdon, UK, 2017.

5. White, R.; Nackoney, J. Drylands, People, and Ecosystem Goods and Services; WRI: Washington, DC, USA, 2003.

6. Middleton, N.; Sternberg, T. Climate Hazards in Deserts: A Review. Earth Sci. Rev. 2013, 126, 48-57. [CrossRef]

7. Haber, H.; Menaldo, V. Rainfall, Human Capital, and Democracy. 2011. Available online: https://papers. ssrn.com/sol3 / papers.cfm?abstract_id=1667332 (accessed on 15 May 2015).

8. CIA World Factbook. 2014. Available online: www.cia.gov/library/publications/the-world-factbook/ (accessed on 14 May 2015).

9. Werrell, C.E.; Femia, F.; Sternberg, T. Did We See It Coming? State Fragility, Climate Vulnerability, and the Uprisings in Syria and Egypt. SAIS Rev. Int. Aff. 2015, 35, 29-46. [CrossRef]

10. Sternberg, T. Chinese drought, bread and the Arab Spring. Appl. Geogr. 2012, 34, 519-524. [CrossRef]

11. Rahim, I.; Rueff, H. Human amplification of climate hazards: 2010 floods in Pakistan. In Climate Hazard Crises in Asian Societies and Environments; Sternberg, T., Ed.; Routledge: Abingdon, UK, 2017.

12. Em-Dat-International Disaster Database. 2016. Available online: www.emdat.be/database (accessed on 14 September 2016).

13. Meigs, P. World Distribution of Arid and Semi-arid Homoclimates. In UNESCO Reviews of Research on Arid Zone Hydrology; United Nations: Paris, France, 1953.

14. Sternberg, T.; Rueff, H.; Middleton, N. Contraction of the Gobi Desert, 2000-2012. Remote Sens. 2015, 7, $1346-1358$. [CrossRef]

15. Kafle, H.K.; Bruins, H.J. Climatic trends in Israel 1970-2002: Warmer and increasing aridity inland. Clim. Chang. 2009, 96, 63-77. [CrossRef] 
16. Trabucco, A.; Zomer, R. Global Aridity Index (Global-Aridity) and Global Potential Evapo-Transpiration (Global-PET) Geospatial Database; CGIAR-CSI: Washington, DC, USA, 2009. Available online: www.csi. cgiar.org/ (accessed on 21 January 2018).

17. Laity, J. Deserts and Desert Environments; John Wiley \& Sons: West Sussex, UK, 2008.

18. Sternberg, T.; Thomas, D.; Middleton, N. Pressurized pastoralism in South Gobi Province, Mongolia: What is the role of drought? Trans. Inst. Br. Geogr. 2009, 34, 364-377. [CrossRef]

19. Stoppato, M.; Bini, A. Deserts; Firefly Books: Toronto, ON, Canada, 2003.

20. Dai, A. Drought under global warming: A review. WIREs Clim. Chang. 2011, 2, 45-65. [CrossRef]

21. Lioubimtseva, E.; Henebry, G.M. Climate and environmental change in arid Central Asia: Impacts, vulnerability, and adaptations. J. Arid Environ. 2009, 73, 963-977. [CrossRef]

22. Harris, I.; Jones, P.; Osborn, T.; Lister, D. Updated high-resolution grids of monthly climatic observationsThe CRU TS3. 10 Dataset. Int. J. Climatol. 2014, 34, 623-642. [CrossRef]

23. Warner, T. Desert Meteorology; Cambridge University Press: Cambridge, UK, 2009.

24. IPCC. Climate Change; Cambridge Press: Cambridge, UK, 2012.

25. UNCCD. Global Drylands: A UN System-Wide Response. 2011. Available online: www.unccd.int/Lists/ SiteDocumentLibrary /Publications/Global_Drylands_Full_Report.pdf (accessed on 12 January 2015).

26. Reynolds, J.F.; Smith, D.M.S.; Lambin, E.F.; Turner, B.L.; Mortimore, M.M.; Batterbury, S.; Walker, B. Global desertification: Building a science for dryland development. Science 2007, 316, 847-851. [CrossRef] [PubMed]

27. Tucker, C.J.; Dregne, H.; Newcomb, W. Expansion and contraction of the Sahara Desert from 1980 to 1990. Science 1991, 253, 299-301. [CrossRef] [PubMed]

28. Scheffran, J.; Battaglini, A. Climate and conflicts: The security risks of global warming. Reg. Environ. Chang. 2011, 11, 27-39. [CrossRef]

29. Sternberg, T.; Edwards, M. Desert dust and health: A Central Asian review and steppe case study. Int. J. Environ. Res. Public 2017, 14, 1342. [CrossRef] [PubMed]

30. Safriel, U.; Adeel, Z. Chapter 22: Dryland systems. In Millennium Ecosystem Assessment. Ecosystems and Human Well-Being; World Resources Institute: Washington, DC, USA, 2005; pp. 623-662.

31. Warner, K.; Hamza, M.; Oliver-Smith, A.; Renaud, F.; Julca, A. Climate change, environmental degradation, migration. Nat. Hazards 2010, 55, 689-715. [CrossRef]

32. Kellenberg, D.K.; Mobarak, A.M. Does rising income increase or decrease damage risk from natural disasters? J. Urban Econ. 2008, 63, 788-802. [CrossRef]

33. IPCC. Climate Change; Cambridge Press: Cambridge, UK, 2007.

34. United Nations Development Programme (UNDP). Human Development Statistical Tables; UNDP: New York, NY, USA, 2015. Available online: hdr.undp.org/en/data (accessed on 27 September 2015).

35. United States Department of Agriculture (USDA). Agricultural Production, Supply, and Distribution; USDA: Washington, DC, USA, 2011. Available online: www.indexmundi.com/agriculture/?Country1/4eg\&;1/ 4wheat\&graph1/4imports (accessed on 30 April 2012).

36. World Bank. Urban Population. 2014. Available online: Data.worldbank.org/indicator/SP.URB.TOTL.IN.ZS (accessed on 27 September 2015).

37. Sternberg, T. Water megaprojects in deserts and drylands. Int. J. Water Resour. Dev. 2015, 32, 1-20. [CrossRef]

38. Mohtadi, S. Climate Change and the Syrian Uprising. Bull. At. Sci. 2012. Available online: http://thebulletin. org/climate-change-and-syrian-uprising (accessed on 16 May 2014).

39. Kelley, C.P.; Mohtadi, S.; Cane, M.A.; Seager, R.; Kushnir, Y. Climate change in the Fertile Crescent and implications of the recent Syrian drought. Proc. Natl. Acad. Sci. USA 2015, 112, 3241-3246. [CrossRef] [PubMed]

40. United Nations. Syria Drought Response Plan; United Nations: New York, NY, USA, 2009. Available online: docs.unocha.org/sites/dms/CAP/2009_Syria_Drought_Response_Plan.pdf (accessed on 27 September 2015).

41. Sternberg, T.; Batbuyan, B. Integrating the Hyogo Framework into Mongolia's disaster (DRR) policy. Int. J. Disaster Risk Reduct. 2013, 5, 1-9. [CrossRef]

42. Adger, W. Vulnerability. Glob. Environ. Chang. 2006, 16, 268-281. [CrossRef]

43. Hochrainer, S.; Mechler, R. Natural disaster risk in Asian megacities: A case for risk pooling? Cities 2011, 28, 53-61. [CrossRef]

44. United Nations. Population Division. Department of Economic and Social Affairs; United Nations: New York, NY, USA, 2013. Available online: www.un.org/en/development/desa/population/ (accessed on 12 January 2015). 
45. Greenwood, S. Water insecurity, climate change and governance in the Arab world. Middle East Policy 2014, 21, 140-156. [CrossRef]

46. Sternberg, T.; Ahearn, A.; McConnell, F. Central Asian 'Characteristics' on China's New Silk Road: The Role of Landscape and the Politics of Infrastructure. Land 2017, 6, 55. [CrossRef]

47. Meiyan, J.; Lianchun, S.; Tong, J.; Zhang, D.; Zhai, J. China's Implementation of Impact and Risk-Based Early Warning; World Meteorological Organization: Geneva, Switzerland, 2015; Volume 64.

48. SADC. Regional Vulnerability Assessment and Analysis Synthesis Report; SADC: Botswana, Gaborone, 2016. Available online: Reliefweb.int/sites/reliefweb.int/files/resources/SADC_RVAA-August-Final-Web.pdf (accessed on 21 January 2018).

49. International Strategy for Disaster Reduction (ISDR). Hyogo Framework for Action 2005-2015: Building the Resilience of Nations and Communities to Disasters; ISDR: Geneva, Switzerland, 2011. Available online: www. preventionweb.net/files/18197_midterm.pdf (accessed on 6 September 2012).

(C) 2018 by the author. Licensee MDPI, Basel, Switzerland. This article is an open access article distributed under the terms and conditions of the Creative Commons Attribution (CC BY) license (http:/ / creativecommons.org/licenses/by/4.0/). 